\title{
DETERMINANTS OF THE STATE POLICY EFFECTIVENESS IN THE FIELD OF SCIENCE IN UKRAINE
}

On the modern stage of Ukrainian society's development, we make findings of the fact that there is no conceptual idea about the content of state policy in the field of science, about the mechanisms of its formation and realization. The foregoing stipulates the necessity of formulation of the completed and perfect theory of state policy in the field of science.

The author of the article has set the purpose through the prism of the analysis of the current legislation norms, as well as critical studying the works of modern scholars, to formulate the author's concept of state policy in the field of science in Ukraine and to define key determinants of its efficiency.

Achievement of the formulated objective is carried out by the assistance of comprehensive and consistent application of the proper scientific tools, presented by such methods of scientific cognition as: logical and semantic, system, structural and logical, by the methods of grouping, deduction, induction, analysis and synthesis, etc.

Results. The author of the article has accomplished analysis of scientific works focused on finding out the content of state policy in the field of science. The author has succeeded to establish that state policy in the field of science is rather often considered from structural point of view, i. e. as derivation, which consists of certain aggregate of elements. In author's opinion, such an approach is mechanical to a certain extent, then those numerous relations and factors, which provide its concerted functioning, remain unaddressed. For solving this task, as noted in the article, it is necessary to determine the state policy in the field of science as a strategy and tactics of state activities in the field of science that corresponds national interests and international standards.

As a result the author makes conclusions that the important stages of forming and, at the same time key determinants of state policy efficiency in the field of science in Ukraine are: forecasting effort, strategic planning and object-oriented programming. To increase the efficiency of the implementation of state policy in the field of science in Ukraine, the author has grounded the necessity of making amendments and alterations to the Law of Ukraine "On Scientific, Research and Technical Activity", which must determine forecasting effort, strategic planning and object-oriented programming as the methods of state regulation and management in the scientific, research and technical activity.

Key words: policy, state policy, state policy in the field of science, science, efficiency, determinants, forecasting effort, strategic planning, object-oriented programming. 


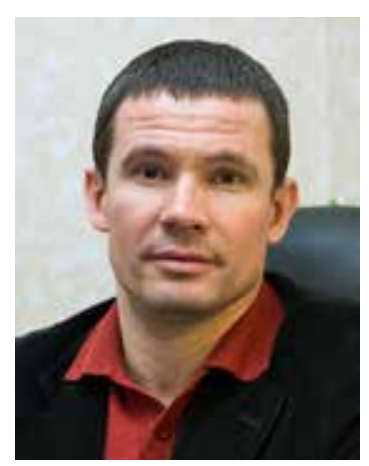

Serhii Mosondz, Vice-Rector for Education and Research of the University of Modern Knowledge,

Doctor of Law, Professor

orcid.org/0000-0003-4417-1074 40533@ukr.net

\section{Introduction}

The proclamation of independence, the formation of a civil society, the change of economic conditions of the economy management, the ideology of the development of market relations in Ukraine - all of those things set new challenges for the authorities regarding public administration in the field of science. In terms of the globalization challenges, the forms of science organization, historically, can not remain unchanged, so there is an urgent need for the transformation of state policy because of the transition from exclusively state science to the creation of new mechanisms of public administration, sources of funding and organization of scientific activities. Besides, due to the complication of the public administration object, where market elements appeared, it is necessary to develop effective mechanisms that would ensure the development of science and at the same time create conditions for improving its economic and social efficiency.

Various theoretical substantiation of state policy in the field of science in general and in Ukraine in particular can be found in the scientific works of such famous scholars as: A. Abdulov, A. Azizov, V. Arutiunov, A. Bezborodov, O. Vahanov, H. Volkov, L. Hokhberh, N. Hordieieva, D. Hvishiani, A. Hudkova, O. Dynkin, H. Dobrov, S. Zdioruk, H. Kalytych, D. Karkavin, K. Korzhavin, V. Kremen, B. Liebin, B. Malitskyi, L. Mindeli, S. Mykulynskyi, O. Popovych, K. Popper, V. Rasudovskyi, A. Sokolov and others.

\section{Previously unsolved problems}

Recently, the Ukrainian state has been actively involved in creating elements of the market innovation system and adapting science as its most important element to new political, social and economic conditions. However, the actions of the public administration agencies in this area were not always systematic and consistent. As a result, new and old forms of organization of science both exist in parallel, and come into conflict to some extent. A number of areas of public administration of science does not have adequate human resources, information and analytical, financial support.

The foregoing requires the need to form a complete and perfect concept of state policy in the field of science in Ukraine and to determine the key determinants of its effectiveness.

\section{Main part}

Speaking about state policy as the category, we must take into account the fact that although the term "state policy" is widely used in the Ukrainian legislation, but it does not contain a clear normative definition of what we should understand under this category.

The analysis of Ukrainian legislation allows us to note the following: 
- first of all, the category of state policy is generally used in a particular context, in linking to specific needs. Thus, for example, the clause 1, Part 1 of the Art. 1 of the Law of Ukraine "On the Principles of State Regional Policy" dated from February 5, 2015 enshrined the definition of "state regional policy" (Verkhovna Rada of Ukraine, 2015);

- secondly, the legislation of Ukraine uses synonymous of the category of state policy. For instance, Part 1 of the Art. 116 of the Constitution of Ukraine notes "the policy of the state", and Part 4 of the Art. 138 uses the term "policy of Ukraine" (Verkhovna Rada of Ukraine, 1996);

- thirdly, there is a special Law of Ukraine "On the Principles of Internal and Foreign Policy" dated from July 1, 2010, which, although does not define the concept of "state policy", but outlines the main principles of the implementation of the internal and foreign state policy of Ukraine (Verkhovna Rada of Ukraine, 2010);

- fourthly, state policy, in the context of realization of its certain directions, is mentioned in a fairly large number of laws of Ukraine and subordinate regulatory acts, for instance, in the Law of Ukraine "On Waste Products" dated from March 5, 1998 (Verkhovna Rada of Ukraine, 1998) or in the Regulations about the Ministry of Regional Development, Building and Housing and Communal Services of Ukraine, approved by the Resolution of the Cabinet of Ministers of Ukraine dated from April 30, 2014 № 197 (Cabinet of Ministers of Ukraine, 2014). At the same time, these acts do not define the category of "state policy";

- fifth, the Ukrainian legislation regulates the main directions of the state policy of Ukraine. It is about the foreign and internal state policy of Ukraine. Thus, in accordance with the Law of Ukraine "On the Principles of Internal and Foreign Policy" dated from July 1, 2010, Ukraine's internal policy consists of: internal policies in the spheres of developing local self-government and stimulating regional development; internal policy in the field of the formation of civil society institutions; domestic policy in the field of national security and defense; internal economic policy; domestic policy in the social sphere; internal policy in the environmental sphere and the sphere of technogenic safety, etc. The principles of Ukraine's foreign policy include: ensuring Ukraine's integration into European political, economic, legal space in order to gaine membership in the European Union; ensuring national interests and security of Ukraine by maintaining peaceful and mutually beneficial cooperation with the members of international community in accordance with generally recognized principles and norms of international law; ensuring protection of the sovereignty, territorial integrity and inviolability of Ukraine's state borders, its political, economic, energy and other interests by diplomatic and other means and methods provided by international law; ensuring protection of the rights and interests of citizens and legal entities of Ukraine abroad; establishment of the leading place of Ukraine in the system of international relations, strengthening international authority of the state, etc.

In case of the lack of a clear definition of the category of "state policy" in the legislation of Ukraine, it is necessary to refer to the works of scholars on this issue. In our opinion, any definition of state policy in the field of science should not contradict the general idea about politics in its traditional sense. 
Thus, politics can be regarded as a consequence of the effects of the external environment and the distribution of power, as well as a set of leading ideas, and as a set of institutional structures, and as a decision-making process (Tertychka, 2002). In the most abstract form, politics represents the sphere of interaction between classes, parties, nations, peoples, states, social groups, power and population, citizens and their associations. It is the most important and complex part of social life (Matuzov, 1997).

The abstract form of understanding politics does not determine a full-fledged approach to ascertaining its content, as there is a lot of controversy surrounding the definition of the most categorical notion. It is due to the multidimensional and multifaceted nature of this phenomenon.

This statement is confirmed by the historical fact, the essence of which is reduced to the fact that the issues of politics, state, society constantly attracted attention of thinkers of different eras and peoples. In the history of political thought, we distinguish such classical works on social philosophy as "State" and "Laws" by Plato, "Politics" by Aristotle, "On the State" and "On the Laws" by Cicero, "The Prince" by Machiavelli, "Leviathan" by Hobbes, "A Political Treatise" by Spinoza, "The Spirit of Laws" by Montesquieu, "On the Social Contract" by Rousseau, "The Metaphysical Foundations on Natural Science" by Kant, "Grundlagen des Naturrechts" by Fichte, "Philosophy of Law" by Hegel, as well as the works by Locke, Weber, Jaspers and other thinkers of the past and present time. However, it should be noted that the works of the ancient pillars of public opinion study not so much politics as a certain kind of state activity, but as a political world in the modern sense (Gadzhiev, 1997).

The problem of state policy in the national scientific literature has not yet been adequately covered, but some issues of this problem, namely: conceptual foundations of state policy, its analysis, means of implementation, etc. set out in the writings of some domestic scholars. Thus, the conceptual foundations for understanding the state policy in general can be reduced to the following formulations:

- state policy is the political activity of the state and its institutions aimed at ensuring order in society, harmonizing and subordinating various social interests, achieving social harmony and organizing the management of the development of social processes (Lohunova et al., 1999);

- state policy is relatively stable, organized and purposeful activity (inaction) of state institutions, carried out by them directly or indirectly regarding a certain problem or a set of problems that affect the life of society (Rebkalo, Tertychka, 2002);

- state policy is a relatively stable, organized and purposeful government activity in relation to a particular problem or object of consideration, which is carried out directly or indirectly through authorized agents and affects the life of society (Romanov et al., 2003).

In turn, state policy is reflected in its functions. It is well-known that the main function for the modern legal state is to protect the interests of a man, to protect his rights and freedoms, to ensure proper living conditions. Other functions of the state are, to any extent, subordinated to its implementation. Among them, one can distinguish, first of all, the creation of democratic conditions for the definition and coordination of interests of various social groups of society; and secondly, the creation of conditions for the devel- 
opment of production; thirdly, the promotion of education, science and culture; fourthly, environmental protection; fifth, protection of the constitutional system; sixth, ensuring law and order.

In this regard, one can talk about state policy in various spheres of society. For instance, we talk about social, cultural, scientific, economic, regulatory, environmental, legal policy of the state. Thus, state policy is reflected in the purpose to regulate social relations, which are formed in real life.

The issue of the very nature of state policy in the field of science also causes contentious debate, reflecting the divergent views of scholars and practitioners on the role of the state in the scientific system. In this context, we consider it necessary to analyze the modern approaches of Ukrainian scholars to the conceptual category titled in this article, which can be reduced to understanding in narrow and broad aspects.

B.A. Malytskyi in the broad sense defines state policy in the field of science as the long-term behavior of the state in regard to the issues related to science (Malytskyi, 2001).

Representatives of the narrow approach perceive the state policy in the field of science as the totality of actions of state officials (state authorities, which they personify), aimed at resolving problems encountered in the process of human activities in the field of science (Zdioruk, 2006; Kalytych, Korzhavin, 2008). They distinguish among the types of principles for the formation of state policy in the field of science the following ones: legislative, normative and purely political (personal). The first two directions are often combined with one another, the latter is mainly considered in the context of an individual's role in the state process because of the complexity of distinguishing the actions of some political leaders in making a political decision, especially when the change of policy direction occurs contrary to the current legislative and normative principles of the activity.

The analysis of the above definitions indicates that state policy is often viewed from structural positions, that is, as an entity consisting of a certain set of elements. This approach is mechanical to a certain extent, because those numerous relations and factors that ensure its smooth functioning remain unaddressed. That is why, in our deep conviction, it is necessary to distinguish two aspects - strategic and tactical as the basis of understanding the state policy.

Taking the following scientific provisions as the basis, we can define state policy as a strategy and tactics that determines the state's activities in a certain area of life of society and the state. Such an activity is carried out by the state systematically in order to achieve certain socially useful results. In our opinion, this very approach to the understanding of state policy allows us to show its teleological nature, i.e. that it is aimed at achieving a certain specific goal, which should be determined by the state policy strategy in a particular field. This, however, does not exclude the possibility that there may be intermediate goals, which achievement is determined by the tactics of state policy and achievements of which are a certain stage in the reaching the general goal of state policy in a particular field.

Taking into account the above mentioned, in our opinion, state policy in the field of science can be nominated as a strategy and tactics of state activity in the field of science, which is in line with national interests and international standards. At the same time, 
the important stages of the formation and, at the same time, the key determinants of its effectiveness are forecasting effort, strategic planning and object-oriented programming.

Forecasting effort in the field of science is scientifically grounded hypothesis about the possible state of science in the future, depending on the nature of the forecast background, as well as on the terms and means of achieving the set goals. The modern stage of social development is saturated with spontaneous events, paradoxical phenomena and uncontrolled processes capable of instantly redrawing the image of the future. Under such conditions, no primary forecast (especially medium or long-term) remains forever relevant - from the moment of creation to the end of the action. Under the pressure of random factors, the difference between the initial parameters of the forecast and the actual socio-economic indicators is increasing, until it reaches a critical limit. After this, the forecast finally loses relations with reality, and the programs and plans developed on its basis lose their practical importance.

Only the regular corrections due to changes in the object of regulation and the environment (forecast background) can stop the prognosis "devaluation" of the forecast. Only a systematic correction allows us to ensure the proper flexibility of the forecast, its adequacy to the current situation, and "consistency" with objective tendencies. Thus, scientifically-based forecasting is not simply a basic forecasting (forecast of socio-economic development, forecast of the effectiveness of planned activities, etc.). It is also their continuous refinement at all stages of the process.

Unfortunately, prognostic activities in the field of science are often carried out by evasion of the methodology. Over the past decades, any conceptual or programmatic document on science issues has been reviewed in regard to the relevance of forecasting. Appropriate forecasts remained in force even when their unreality became apparent from the very beginning. In general, prediction in the field of science has limited, static nature. It is carried out only at the previous stages of making strategic decisions and never accompanies the process of their implementation.

Touching upon the problems of forecasting, it is impossible to evade the issue of verification. Verification is an important part of the forecasting process. In the course of verification, the degree of reliability of the forecasts is determined, their gaps are clarified, the causes of the errors are established. In turn, the obtained information helps to rationalize the forecast activity, to avoid past failures and to improve overall planning effectiveness.

Verification is important not only in terms of summing up the final results of the forecast. It is expedient and desirable at the stage of its development. Preliminary verification - is an effective tool for checking the forecasts for the compliance with the requirements of modern science, the calculation of the probability of their implementation for the given confident intervals, assessment of their functional completeness.

Unfortunately, forecasting in the field of science is not supported by verification either at the initial stage or in the final phase. This is precisely why one can explain the fact that many of the forecasts lose relevance shortly after their development, and their methodological errors are replicated with constant consistency.

Strategic planning is the mean of formal prediction of future problems and opportunities in both any sphere and the field of science. 
Strategic planning in the field of science is the key element of strategic public administration in the development of science, which helps authorities responsible for the implementation of scientific policy directions to make decisions that are coordinated with the approaches to the realization of their functions, objectives and tasks.

\section{The role of strategic planning in forming state policy}

The role of strategic planning in forming state policy in the field of science can not be overestimated that allows consolidating resource potential in the most important areas of government activity, rational distribution of existing forces and resources, avoiding various imbalances, unnecessary steps, and wasteful expenditures. Finally, the flexibility of the state policy in the field of science in Ukraine, its tolerance to crisis phenomena and adequacy to the challenges of time precisely depend on the strategic planning in the field of science.

At the present stage of the development of Ukrainian society, the serious disadvantage of strategic planning both in any sphere and in the field of science is its discrete nature. In accordance with the current legislation, the development of state target-oriented programs and their concepts is carried out on the initiative of public authorities by the actualization of certain problems of social life (Law of Ukraine "On State Target Programs") (Verkhovna Rada of Ukraine, 2004). In practice, this means that the target-oriented programs (concepts) are adopted not with a predetermined periodicity, but depending on a number of objective and subjective factors, such as: the existence of a certain problem, the existence of political will to solve it, the appropriateness of socio-political situation, etc. And this leads to the fact that unresolved problems continue to be escalated and gain increasing scales.

The main form of planning in the field of science is the development of state target-oriented programs aimed at solving the most important problems of the development of science.

State target-oriented programming in the field of science is an algorithm for developing a set of interrelated tasks and measures aimed at solving the most important problems of science development, are carried out by the usage of the funds of the State Budget of Ukraine and agreed upon by terms of execution, composition of performers, resource provision.

State target-oriented scientific, research and technical programs are the main mean of concentration of scientific and technical potential of the state for solving the most important natural, technical and humanitarian problems and realization of the priority directions of science and technology development.

The key points of state target-oriented programming in the field of science are: identification and systematization of strategic goals; development of an integrated system of measures aimed at their achievement; construction of a clear algorithm for the implementation of the planned activities (with a preliminary definition of the performers, sources and amounts of financing); maximum determination of planned parameters, criteria, indicators; the presence of control mechanisms and responsibility for the achieved results. Thus, state target-oriented programming in the field of science is characterized by complexity, multi-parameter nature, algorithmics, applied orientation and imperativeness. 
Unfortunately, the development, adoption and implementation of most of the science-related programs is outside the unified legal field. There are currently no legislative acts or, at least, government decrees that would establish general requirements for non-targeted program documents, would regulate the procedure for their creation, would provide control over their implementation. This, on the one hand leads to a huge difference in programming, and on the other - stipulates the irresponsibility of its subjects.

Taking into account the above scientific considerations, we can state that the reasonableness of state policy in the field of science, its purposefulness, reality and efficiency depend on the quality of forecasting effort, planning and programming. At the same time, even minor mistakes in their implementation may turn into serious problems while solving important political tasks. That is why, in our opinion, it is expedient to make amendments to the Art. 56 of the Law of Ukraine "On Scientific, Research and Technical Activity" and to supplement it with the Art. 56-1, which should define forecasting effort, strategic planning and object-oriented programming as the methods of state regulation and management in scientific, research and technical activity. To this end, the Articles 56 and 56-1 of the above-mentioned Law shall be worded as follows:

Article 56. Forecasting Effort in the Field of Scientific, Research and Technical Activity

Forecasting effort in the field of scientific, research and technical activity is a scientifically grounded hypothesis about the possible state of scientific, research and technical activity in the future, depending on the nature of the forecasting background, as well as about the terms and means of achieving the set objectives.

Forecasts of the state of scientific, research and technical activity are developed for short-term (1-3 years) and medium-term (5 years) periods.

The central executive authority in the field of science is responsible for developing the forecasts for the state of scientific, research and technical activity.

Forecasts of the state of scientific, research and technical activity are being developed in accordance with the procedure established by the Cabinet of Ministers of Ukraine.

Indicators for predicting the state of scientific, research and technical activity serve as the basis for the development of state target-oriented programs on science issues.

Article 56-1. Planning in the Field of Scientific, Research and Technical Activity

The main form of planning in the field of scientific, research and technical activity is the development of state target-oriented programs aimed at solving the most important problems of science development.

State target-oriented scientific, research and technical programs are developed, approved and implemented on the basis of the Law of Ukraine "On State Target-Oriented Programs", in accordance with the procedure established by the Cabinet of Ministers of Ukraine.

National target-oriented scientific, research and technical programs are developed for a period of five years. Sectoral and local target-oriented scientific, research and technical programs are developed for a period from three up to five years, taking into account the duration of the current national target-oriented programs.

State target-oriented scientific, research and technical programs are the main mean of implementing priority directions of the development of science and technology by con- 
centration of scientific and technical potential of the state for solving the most important natural, technical and humanitarian problems.

State target-oriented scientific, research and technical programs on the priority directions of science and technology development are formed by the central executive authority in the field of scientific, research and technical, innovation activity on the basis of target-oriented projects selected on a competitive basis.

\section{Conclusions}

As a result the author makes conclusions that the important stages of forming and, at the same time key determinants of state policy efficiency in the field of science in Ukraine are: forecasting effort, strategic planning and object-oriented programming. To increase the efficiency of the implementation of state policy in the field of science in Ukraine, the author has grounded the necessity of making amendments and alterations to the Law of Ukraine "On Scientific, Research and Technical Activity", which must determine forecasting effort, strategic planning and object-oriented programming as the methods of state regulation and management in the scientific, research and technical activity.

\section{Bibliography:}

1. Про засади державної регіональної політики : Закон України від 5 лютого 2015 p. № 156-VIII / Верховна Рада України. Відомості Верховної Ради України. 2015. № 13. Ст. 90.

2. Конституція України : Закон України від 28 червня 1996 р. № 254к/96-ВР (станом на 30 вересня 2016 р.) / Верховна Рада України. Відомості Верховної Ради України. 1996. № 30. Ст. 141.

3. Про засади внутрішньої і зовнішньої політики : Закон України від 1 липня 2010 p. № 2411-VI (станом на 8 липня 2018 р.) / Верховна Рада України. Відомості Верховної Ради України. 2010. № 40. Ст. 527.

4. Про відходи : Закон України від 5 березня 1998 р. № 187/98-ВР (станом на 4 жовтня 2018 р.) / Верховна Рада України. Відомості Верховної Ради України. 1998. № 36. Ст. 242.

5. Про затвердження Положення про Міністерство регіонального розвитку, будівництва та житлово-комунального господарства України : Постанова Кабінету Міністрів України від 30 квітня 2014 р. № 197 (станом на 5 травня 2017 р.) / Кабінет Міністрів України. Офіційний вісник України. 2014. № 51. С. 42. Ст. 1345.

6. Про державні цільові програми : Закон України від 18 березня 2004 р. № 1621-IV (станом на 12 жовтня 2018 р.) / Верховна Рада України. Відомості Верховної Ради України. 2004. № 25. Ст. 352.

7. Тертичка В.В. Державна політика: аналіз та здійснення в Україні. Київ : Вид-во Соломії Павличко «ОСНОВИ», 2002. 750 с.

8. Гаджиев К.С. Введение в политическую науку. Москва : Логос, 1997. 544 с.

9. Логунова М.М., Шахов В.А., Шевченко М.Ф. Концептуальні засади теорії політики. Київ : Вид-во УАДУ, 1999. 160 с.

10. Державна політика: аналіз та впровадження в Україні : конспект лекцій до навчального модуля / укл. : В.А. Ребкало, В.В. Тертичка. Київ : Вид-во УАДУ, 2002. 80 с.

11. Романов В.С., Рудік О.М., Брус Т.М. Державна політика: аналіз та механізми її впровадження. Дніпропетровськ : ДРІДУ НАДУ, 2003. 72 с.

12. Актуальні питання методології та практики науково-технічної політики / за ред. Б.А. Малицького. Київ : УкрIНТЕЇ, 2001. 204 с. 
13. Гуманітарна політика Української Держави в новітній період : монографія / за ред. С.І. Здіорука. Київ : НІСД, 2006. 403 с.

14. Калитич Г.І., Коржавін К.М. Науково-технологічний та інноваційний розвиток: концепції, моделі, рішення. Київ : УкрIНТЕІ, 2008. 268 с.

15. Матузов Н.И. Понятие и основные приоритеты российской правовой политики. Правоведение. 1997. № 4. С. 6-17.

\section{References:}

1. Verkhovna Rada of Ukraine (2015). Pro zasady derzhavnoi rehionalnoi polityky: Zakon Ukrainy vid 5 liutoho 2015 r. № 156-VIII [On the Principles of State Regional Policy: Law of Ukraine dated February 5, 2015 № 156-VIII]. Vidomosti Verkhovnoi Rady Ukrainy, no. 13, art. 90 [in Ukrainian].

2. Verkhovna Rada of Ukraine (1996). Konstytutsiia Ukrainy: Zakon Ukrainy vid 28 chervnia 1996 r. № 254к/96-BP (stanom na 30 veresnia 2016 r.) [The Constitution of Ukraine: Law of Ukraine dated June 28, 1996 № 254к/96-BP (as of September 30, 2016)]. Vidomosti Verkhovnoi Rady Ukrainy, no. 30, art. 141 [in Ukrainian].

3. Verkhovna Rada of Ukraine (2010). Pro zasady vnutrishnoi i zovnishnoi polityky: Zakon Ukrainy vid 1 lypnia 2010 r. № 2411-VI (stanom na 8 lypnia 2018 r.) [On the Principles of Internal and Foreign Policy: Law of Ukraine dated July 1, 2010 № 2411-VI (as of July 8, 2018)]. Vidomosti Verkhovnoi Rady Ukrainy, no. 40, art. 527 [in Ukrainian].

4. Verkhovna Rada of Ukraine (1998). Pro vidkhody: Zakon Ukrainy vid 5 bereznia 1998 r. № 187/98-BP (stanom na 4 zhovtnia 2018 r.) [On Waste: Law of Ukraine dated March 5 , 1998 № 187/98-BP (as of October 4, 2018)]. Vidomosti Verkhovnoi Rady Ukrainy, no. 36, art. 242 [in Ukrainian].

5. Cabinet of Ministers of Ukraine (2014). Pro zatverdzhennia Polozhennia pro Ministerstvo rehionalnoho rozvytku, budivnytstva ta zhytlovo-komunalnoho hospodarstva Ukrainy : Postanova Kabinetu Ministriv Ukrainy vid 30 kvitnia 2014 r. № 197 (stanom na 5 travnia 2017 r.) [On Approval of the Regulation on the Ministry of Regional Development, Construction and Housing and Communal Services of Ukraine: Resolution of the Cabinet of Ministers of Ukraine dated April 30, 2014 № 197 (as of May 5, 2017)]. Ofitsiinyi visnyk Ukrainy, no. 51, pp. 42, art. 1345 [in Ukrainian].

6. Verkhovna Rada of Ukraine (2004). Pro derzhavni tsilovi prohramy: Zakon Ukrainy vid 18 bereznia 2004 r. № 1621-IV (stanom na 12 zhovtnia 2018 r.) [On State Target Programs: Law of Ukraine dated March 18, 2004 № 1621-IV (as of October 12, 2018)]. Vidomosti Verkhovnoi Rady Ukrainy, no. 25, art. 352 [in Ukrainian].

7. Tertychka, V.V. (2002). Derzhavna polityka: analiz ta zdiisnennia v Ukraini [State Policy: Analysis and Implementation in Ukraine]. Kyiv: OSNOVY [in Ukrainian].

8. Gadzhiev, K.S. (1997). Vvedenie v politicheskuiu nauku [Introduction to political science]. Moscow: Logos [in Russian].

9. Lohunova, M.M., Shakhov, V.A., Shevchenko, M.F. (1999). Kontseptualni zasady teorii polityky [Conceptual foundations of the theory of politics]. Kyiv: UADU [in Ukrainian].

10. Rebkalo, V.A., Tertychka, V.V. (eds.) (2002). Derzhavna polityka: analiz ta vprovadzhennia v Ukraini: konspekt lektsii do navchalnoho modulia [State Policy: Analysis and Implementation in Ukraine: a summary of lectures to the curriculum]. Kyiv: UADU [in Ukrainian].

11. Romanov, V.Ye., Rudik, O.M., Brus, T.M. (2003). Derzhavna polityka: analiz ta mekhanizmy yii vprovadzhennia [State policy: analysis and mechanisms for its implementation]. Dnipropetrovsk: DRIDU NADU [in Ukrainian]. 


\title{
ОСОБЛИВЕ АДМІНІСТРАТИВНЕ ПРАВО
}

12. Malytskyi, B.A. (ed.) (2001). Aktualni pytannia metodolohii ta praktyky naukovo-tekhnichnoi polityky [Topical issues of methodology and practice of scientific and technical policy]. Kyiv: UkrINTEI [in Ukrainian].

13. Zdioruk, S.I. (2006). Humanitarna polityka Ukrainskoi Derzhavy v novitnii period: monohrafiia [Humanitarian policy of the Ukrainian state in the modern period: a monograph]. Kyiv: NISD [in Ukrainian].

14. Kalytych, H.I., Korzhavin, K.M. (2008). Naukovo-tekhnolohichnyi ta innovatsiinyi rozvytok: kontseptsii, modeli, rishennia [Scientific, technological and innovative development: concepts, models, solutions]. Kyiv: UkrINTEI [in Ukrainian].

15. Matuzov, N.I. (1997). Poniatie i osnovnye prioritety rossiiskoi pravovoi politiki [The concept and main priorities of the Russian legal policy]. Pravovedenie, no. 4, pp. 6-17 [in Russian].

\section{ДЕТЕРМІНАНТИ ЕФЕКТИВНОСТІ ДЕРЖАВНОЇ ПОЛІТИКИ У СФЕРІ НАУКИ В УКРАЇНI}

\author{
Сергій Мосьондз, \\ проректор з навчальної та наукової роботи Університету сучасних знань, \\ доктор юридичних наук, професор \\ orcid.org/0000-0003-4417-1074 \\ 40533@ukr.net
}

На сучасному етапі розвитку українського суспільства констатується факт відсутності концептуального уявлення про зміст державної політики у сфері науки, про механізми ії формування та реалізації. Викладене зумовлює необхідність формулювання завершеної та досконалої теорії державної політики у сфері науки.

У статті поставлена мета крізь призму аналізу норм чинного законодавства, а також критичного вивчення праџь сучасних учених сформулювати авторську концепцію державної політики у сфері науки в Україні та визначити ключові детермінантами ї̈ ефективності.

Досягнення сформульованої мети здійснюється за допомогою комплексного й послідовного застосування відповідного наукового інструментарію, представленого такими методами наукового пізнання, як логіко-семантичний, системний, структурно-логічний, методи групування, дедукиії, індукиії, аналізу та синтезу тощо.

Результати. У статті проведено аналіз наукових доробків, присвячених з'ясуванню змісту державної політики у сфері науки. Автору вдалося встановити, щео державну політику у сфері науки досить часто розглядають зі структурних позицій, тобто як утворення, щуо складається з певної сукупності елементів. На думку автора, такий підхід є певною мірою механічним, адже поза увагою залишаються ті численні зв 'язки й фактори, які забезпечують ії злагоджене функціонування. Для вирішення цьвого завдання необхідно державну політику у сфері науки номінувати як стратегію та тактику діяльності держави у сфері науки, щэо відповідає національним інтересам $i$ міжнародним стандартам.

Як підсумок робиться висновок про те, щэо важливими етапами формування $\check{u}$ водночас ключовими детермінантами ефективності державної політики у сфері науки в Украӥні є прогнозування, стратегічне планування та цільове 
НАУКОВЕ ПРАВО

програмування. Для підвищення ефективності здійснення державної політики у сфері науки в Украйні обтрунтовано необхідність внесення змін і доповнень до Закону Украӥни "Про наукову і науково-технічну діяльність», у якому варто серед методів державного регулювання ци управління в науковій $і$ науково-технічній діяльності визначити прогнозування, стратегічне планування та цільове програмування.

Ключові слова: політика, державна політика, державна політика у сфері науки, наука, ефективність, детермінанти, прогнозування, стратегічне планування, цільове програмування. 